\title{
THE YIELD AND QUALITY PROPERTIES OF CHICKPEA SEEDS (CICER ARIETINUM L.) AFFECTED BY HARVEST TIMES
}

\author{
S. GÜRSOY ${ }^{1^{*}}$ \\ *E-mail: songul.gursoy@dicle.edu.tr
}

Received: Feb. 03, 2020. Revised: Feb. 11, 2020. Accepted: Feb. 15, 2020. Published online: June 5, 2020

\begin{abstract}
Harvesting of chickpea (Cicer arietinum L.) seeds at right time of maturity is one of the important issues because pod dropping and shattering is a major problem during harvest. Also, the physical properties of chickpea seeds can be affected by harvest time. For this purpose, a field experiment was carried out to examine the effects of harvest times after physiological maturity on the seed yield per plant and the seed quality properties in chickpea production. The treatments used in the experiment consisted of five harvest times, which chickpea pods were harvested at physiological maturity (H1) and 5, 10, 15, and 20 days after physiological maturity (H2, H3, H4 and H5, respectively). The physiological maturity time (R7) was considered as the stage that leaves start to yellow and $50 \%$ of pods are yellow. Moisture content, dimension properties, hundred seed weight, true density, bulk density and porosity and seed yield per plant was determined in the study. The results showed that all measured variables were affected by harvest time. The true density and porosity increased with
\end{abstract}

delayed harvest time. But, the other measured variables decreased when harvest was delayed.

Keywords: harvest stage; seed quality; physiological maturity; density.

\section{INTRODUCTION}

Chickpea is one of the most important grain legumes used extensively for human consumption in the world because its seeds are very rich in protein, starch, fiber, minerals and vitamins (Jukanti et al., 2012). Especially, chickpea is considered as one of the essential food protein in developing countries. Chickpea grain is also a good source of carbohydrates, important minerals and important vitamins (Cabrera et al., 2003; Khan et al., 2015). Therefore, it is used in many areas of food and feed industry.

Harvest time is very critical factor in chickpea production because it significantly affects seed yield and

\footnotetext{
${ }^{1}$ Agricultural Machinery and Technologies Engineering Department, Dicle University, Diyarbakır, Turkey
} 


\section{S. GÜRSOY}

quality. Therefore, chickpea seeds should be harvested at right time to obtain higher seed yield and quality (Gnyandev et al., 2019). Yadav et al. (2005) reported that both early and late harvest reduced chickpea yield and seed quality. Also, Khatun et al. (2010) stated that the on-time harvest of chickpea was very important issue for good quality with higher yield because early harvest results in poor seed quality due to high percentage of immature seeds and high seed moisture content, and late harvest cause the loss of yield due to pod drop and shattering. Therefore, the studies to determine the ideal harvest time in chickpea production are important to obtain better seed quality and higher crop yield. Morphological and physiological changes in plants and seed during the maturation process have been used as parameters to identify harvest time in chickpea production (Gnyandev et al., 2019). Chickpea is commonly suggested to harvest at a time as close as possible to the physiological maturity, that is after the stabilization of dry matter translocation to the seeds. Also, seed moisture must be at suitable level for management processes, such as harvesting, storage, handling and processing systems. However, there is still lacking information about how harvest times affect seed properties.

Certain physical properties of grain and seed have been used as an indicator of product quality. For example, moisture content is one of the important features that are considered in the storage of the product. The physical properties of seed (size, bulk density, true density etc.) are the major factor in determining the marketability of a chickpea crop (Chang, 1988). Knowledge of seed physical properties is also important in sizing, sorting, sieving, storage and other handling processes (Nikobin et al., 2009; Wood et al., 2011). The objective of this study is to determine the effects of different harvest times on the grain yield per plant and seed physical properties (seed moisture content, seed sizes, hundred seed weight, true density, bulk density and porosity) in chickpea production.

\section{MATERIAL AND METHODS}

A field experiment was conducted at Dicle University, Agriculture Faculty Experiment Area in Diyarbakır, Turkey $\left(37^{\circ} 55^{\prime} 36^{\prime \prime} \mathrm{N}, \quad 40^{\circ} 13^{\prime} 49^{\prime \prime} \mathrm{E}\right.$ and $670 \mathrm{~m}$ above sea level), from February to July 2019. The experimental site is characterized by deep, well-drained loam soil and a semi-arid climate (humid winters and dry summers). Monthly rainfalls, average temperature and relative humidity records during the experimental year (2019) are shown in Table 1. The seedbed preparation included disc harrow tillage at 15-20 cm depth in October, and cultivator at $10-15 \mathrm{~cm}$ and planking three days before seeding. The chickpea seed (variety: Diyar-95) was sown on the $25^{\text {th }}$ of February by hand. The seeding rate was 55 seed $\mathrm{m}^{-2}$ and seeding depth was approximately $6 \mathrm{~cm}$. The space between rows was $45 \mathrm{~cm}$. The hand weeding was applied twice, at 20 and 40 days after seeding.

The experiment was conducted by using the completely randomized block 


\section{EFFECTS OF HARVEST TIMES ON CHICKPEA SEEDS}

design with three replications. The treatments used in the experiment consisted of five harvest times; chickpea pods were harvested at physiological maturity (H1) and 5, 10, 15, and 20 days after physiological maturity $(\mathrm{H} 2, \mathrm{H} 3, \mathrm{H} 4$ and $\mathrm{H} 5$, respectively). The harvest at physiological maturity stage (R7) was carried out when leaves start to yellow and $50 \%$ of pods are yellow.

Table 1 - Monthly rainfall, average temperature, relative humidity during experimental year and long term average

\begin{tabular}{lllllll}
\hline \multirow{2}{*}{ Months } & \multicolumn{2}{l}{ Rainfall $(\mathbf{m m})$} & \multicolumn{2}{l}{ Average temperature $\left({ }^{\circ} \mathrm{C}\right)$} & \multicolumn{2}{l}{ Relative humidity (\%) } \\
\cline { 2 - 7 } & $\begin{array}{l}\text { Growing } \\
\text { season } \\
(\mathbf{2 0 1 9 )}\end{array}$ & $\begin{array}{l}\text { Long- } \\
\text { term }\end{array}$ & $\begin{array}{l}\text { Growing } \\
\text { season } \\
\mathbf{( 2 0 1 9 )}\end{array}$ & $\begin{array}{l}\text { Long- } \\
\text { term }\end{array}$ & $\begin{array}{l}\text { Growing } \\
\text { season } \\
(\mathbf{2 0 1 9 )}\end{array}$ & Long-term \\
\hline January & 67.2 & 71.2 & 5.8 & 1.7 & 81.7 & 76.0 \\
\hline February & 77.4 & 67.0 & 5.4 & 3.7 & 77.0 & 71.6 \\
\hline March & 135.2 & 68.0 & 8.2 & 8.3 & 74.9 & 65.0 \\
\hline April & 152.6 & 68.5 & 11.8 & 13.8 & 78.4 & 63.0 \\
\hline May & 42.8 & 43.8 & 20.1 & 19.2 & 58.5 & 55.0 \\
\hline June & 1.0 & 8.2 & 28.3 & 26.2 & 32.5 & 35.0 \\
\hline
\end{tabular}

\section{Measurements}

To determine the effects of harvest times on the grain yield per plant and the seed properties of chickpea, the 10 plants randomly selected at each plots was harvested by hand on each harvest stages and seeds was separated from pods by hand.

The grain yield per plant was determined by weighting the seeds at each plots and dividing by 10 plants.

The moisture content of seed samples was determined according to the Approved Method ASABE S352.2 air oven method (ASABE Standards, 1998).

The physical dimensions of chickpea seeds were determined randomly measuring the length, width and thickness of 20 seeds by a digital caliper (Mitutoyo Corporation, Japan) having least count of $0.01 \mathrm{~mm}$ (Fig. 1).

The arithmetic and geometric mean diameter of chickpea seeds was calculated by using Equation (1, 2) (Mohsenin, 1986).

$$
\begin{aligned}
& D_{a}=(L+W+T) / 3 \\
& D_{g}=(L W T)^{1 / 3}
\end{aligned}
$$

where, $\mathrm{L}=$ seed length, $W=$ seed width, $T=$ seed thickness, $D_{a}=$ arithmetic mean diameter of seed, $D_{g}=$ geometric mean diameter of seed.

The hundred seed mass was determined by using an electronic balance (WL-3002L) to an accuracy of $0.01 \mathrm{~g}$.

The bulk density of chickpea seeds $\left(\rho_{b}\right)$ is determined by measuring the volume of a known mass of seeds into a graduated cylinder of $250 \mathrm{ml}$ (readable to $2 \mathrm{ml}$ ) (Haque et al., 2009).

The true density of chickpea seeds $\left(\rho_{t}\right)$ was determined using water displacement technique (Shepherd and Bhardwaj, 1986).

The porosity of the bulk seeds $(\varepsilon)$ was computed from the values of the true density and the bulk density using the Equation (3) given by Mohsenin (1986).

$$
\varepsilon=100 \times\left[1-\left(\rho_{b} / \rho_{t}\right)\right]
$$

where, $\varepsilon=$ prosity, $\rho_{b}=$ bulk density of chickpea seeds, $\rho_{t}=$ true density of chickpea seeds.

Analysis of variance (ANOVA) was conducted using the JMP statistical 


\section{S. GÜRSOY}

software (SAS Institute Inc., 2002) to examine the effects of the harvest times on the seed yield per plant and the seed properties. Means of measured variables were compared among harvest times using the least significant difference test at 5\% significant level. The relationship between the harvest times and measured variables was determined using regression analysis of the JMP statistical software. The well-fitting regression model was chosen as the one with the highest coefficient of determination and the least residual mean square and the mean relative percent error.

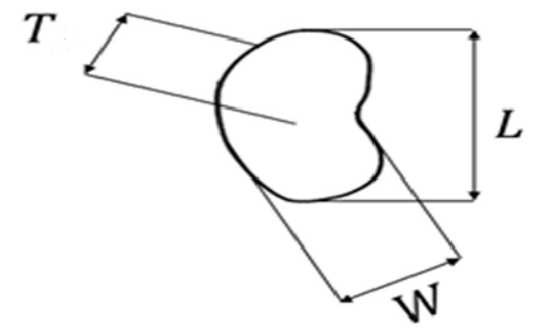

Figure 1 - Principal dimensions of chickpea seeds: $L=$ length; $\mathrm{W}=$ width; $\mathrm{T}=$ thickness

\section{RESULTS AND DISCUSSION}

The analysis of variance (ANOVA) for the grain weight per plant and seed physical properties as affected by the harvest stages is shown in Table 2. The harvest times affected the grain weight per plant, moisture content, thickness, arithmetic mean diameter, geometric mean diameter, and porosity at $1 \%$ probability level $(P<0.01)$, and length, width, 100 seed weight, bulk density at $5 \%$ probability level $(P<0.05)$.

Fig. 2 shows the variation of the grain yield per plant with the harvest times of chickpea seeds. Relationship between the grain yield per plant and the harvest time was significant $(P<0.01)$ and the second order polynomial models was selected as a suitable model to predict the grain yield per plant as a function of harvest times. The grain yield per plant was the highest at the $\mathrm{H} 1$ (harvest at physiological maturity stage) and decreased at an increasing rate until H3 (harvest at 10 days after physiological maturity stage), then at a decreasing rate. The results of this study showed that the 20 days delay of harvest time in chickpea production reduced the grain yield per plant by $49.24 \%$. The decrease in the grain yield per plant with delay in harvest time may be attributed to the increase in seed losses due to pod drop. Also, the decreased 100 seed weight with delayed harvest (Fig. 5) could result in decreasing the grain yield per plant. These findings is in agreement with Philbrook and Oplinger (1989) and Isaac et al. (2016), who reported that late harvest caused the loss of seed yield in soybean agriculture. Also, Cassells and Caddick (2010) reported that late harvest resulted in excessive yield losses, due to pod drop and shattering in chickpea production.

The relationship between the harvest times and the moisture content of seed is represented in Fig. 3. The moisture content of seed was the highest $(37.18 \%)$ at the $\mathrm{H} 1$ and decreased at a decreasing rate with increased harvest time. The average moisture content of seed was $14.39 \%$, $11.85 \%, 9.88 \%, 9.31 \%$ at $\mathrm{H} 2, \mathrm{H} 3, \mathrm{H} 4$, 


\section{EFFECTS OF HARVEST TIMES ON CHICKPEA SEEDS}

H5 harvest times, respectively. The decrease in the seed moisture content with delayed harvest times may be due to loss of water from the seed during seed development. Similar results were also observed by Bharud and Patil (1990) and Gnyandev et al. (2019). Chickpea is recommended to be harvested at the $14 \%$ to $16 \%$ seed moisture content to reduce seed damage because its seeds can crack or split when harvested at low seed moisture content. However, it is stated that above $14 \%$ moisture content can reduce the safe storage for extended period (DAFF, 2012).

The length, width and thickness of chickpea seeds was linearly decreased with increased harvest time
(Fig. 4a). The 20 days delay of harvest time decreased the length, width and thickness of seeds by $9.38 \%, 10.20 \%$, $12.33 \%$, respectively. The calculated arithmetic and geometric mean diameter of seeds decreased as polynomial with delayed harvest times (Fig. 4b). The decreased dimensions properties of seed with delay of harvest time may be attributed to the shrinkage of seed due to the decrease of seed moisture content with the delay in harvest time (Fig. 3). Sologubik et al. (2013) stated that the increase in the seed moisture content could cause the expansion of the seed as a result of moisture absorption in the intracellular spaces inside the seeds.

Table 2 - Analysis of variance (ANOVA) for the grain weight per plant and seed properties as affected by the harvest times ${ }^{1}$

\begin{tabular}{|c|c|c|c|c|c|c|}
\hline $\begin{array}{l}\text { Source of } \\
\text { variation }\end{array}$ & $\begin{array}{l}\text { GW } \\
\text { (g/plant) }\end{array}$ & $\begin{array}{l}\mathrm{MC} \\
(\%)\end{array}$ & $\begin{array}{l}\mathrm{L} \\
(\mathrm{mm})\end{array}$ & $\begin{array}{l}W \\
(\mathrm{~mm})\end{array}$ & $\begin{array}{l}\mathrm{T} \\
(\mathrm{mm})\end{array}$ & $\begin{array}{l}\mathrm{Da} \\
(\mathrm{mm})\end{array}$ \\
\hline Harvest time & ** & ** & & * & ** & ** \\
\hline Std Error & 0.318 & 1.349 & 0.184 & 0.165 & 0.078 & 0.117 \\
\hline C.V. & 11.13 & 14.15 & 3.28 & 3.45 & 1.71 & 2.31 \\
\hline $\begin{array}{l}\text { Source of } \\
\text { variation }\end{array}$ & $\begin{array}{l}\mathrm{Dg} \\
(\mathrm{mm})\end{array}$ & $\begin{array}{l}\text { As } \\
\left(\mathrm{mm}^{-2}\right)\end{array}$ & $\begin{array}{l}\text { HSW } \\
\text { (g) }\end{array}$ & $\begin{array}{l}\rho_{\mathrm{t}} \\
\left(\mathrm{g} \mathrm{cm}^{-3}\right)\end{array}$ & $\begin{array}{l}\rho_{b} \\
\left(\mathrm{~g} \mathrm{~cm}^{-3}\right)\end{array}$ & $\begin{array}{l}E \\
(\%) \\
\end{array}$ \\
\hline Harvest time & ** & ${ }_{* *}^{* *}$ & 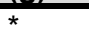 & ** & * & ${ }^{* *}$ \\
\hline Std Error & 0.114 & 6.461 & 3.432 & 0.058 & 0.031 & 3.047 \\
\hline C.V. & 2.27 & 4.71 & 13.23 & 6.43 & 7.94 & 9.31 \\
\hline
\end{tabular}

$1, *, * *$ and ns refer to significant treatment effects in ANOVA at $P<0.05, P<0.01$ and not significant, respectively. $\mathrm{GW}=$ grain weight per plant; $M C=$ moisture content; $L=$ length; $W=$ width; $T=$ thickness; $\mathrm{Da}=$ arithmetic mean diameter; $\mathrm{Dg}=$ geometric mean diameter: $\mathrm{As}=$ surface area; $\mathrm{HSW}=100$ seed weight; $\rho_{\mathrm{t}}=$ true density; $\rho_{\mathrm{b}}=$ bulk density; $\varepsilon=$ porosity.

Fig. 5 shows that the 100 seed weight of chickpea was the highest at the H1 (harvest at physiological maturity stage) and decreased at an increasing rate until $\mathrm{H} 2$ (harvest at five days after physiological maturity stage), then at a decreasing rate. The 20 days delay of harvest time decreased the hundred seed weight by $34 \%$. Those results are in agreement with the findings of Mehta et al. (1993) and Gaikwad and Bharud (2017), who determined that the hundred seed weight significantly decreased after physiological maturity. This decrease in the hundred seed 


\section{S. GÜRSOY}

weight could be due to the loss of the utilization in various physiological moisture content in seed or the and metabolic processes like disruption of vascular connection and respiration etc. (Mehta et al., 1993).

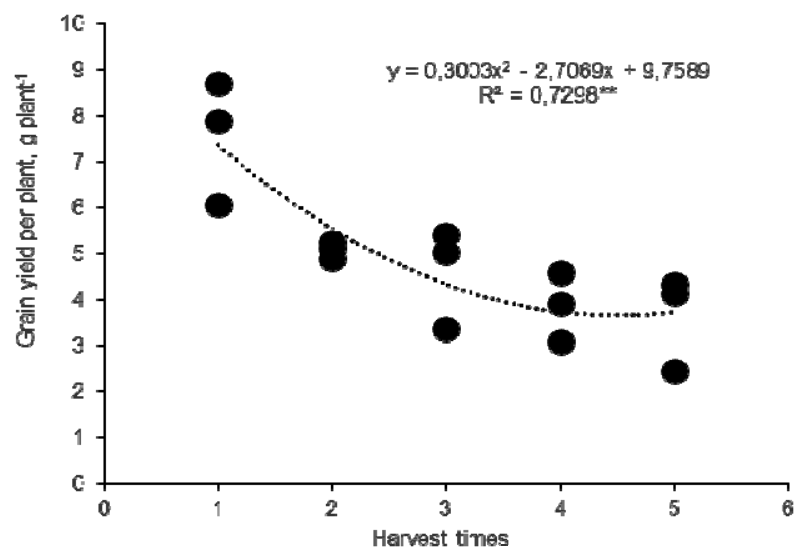

Figure 2 - The grain yield per plant affected by the harvest times of chickpea

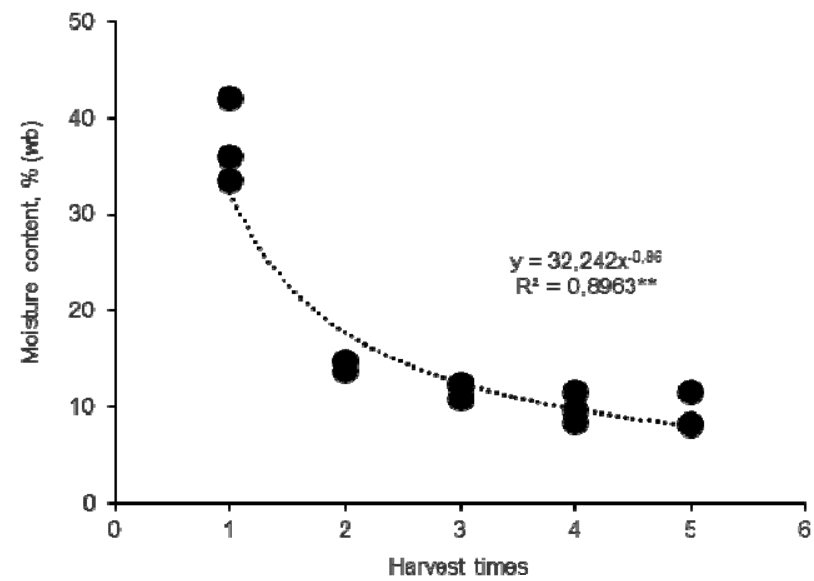

Figure 3 - The moisture content of chickpea seeds affected by the harvest times

The true and bulk density of chickpea seeds varied from 1.245 to $1.986 \mathrm{~g} \mathrm{~cm}^{-3}$ and from 0.740 to $0.590 \mathrm{~g} \mathrm{~cm}^{-3}$, at different harvest times, respectively. The true density increased as polynomial at an increased rate with delay in harvest time. The 20 days delay of harvest time after physiological maturity in creased the true density of seed by $60 \%$ (Fig. 6 ). The fact that the true density increased with the delay of harvest time after physiological maturity could be resulted from significantly reduced seed volume according to the decrease in the mass of seed, due to moisture content loss. 


\section{EFFECTS OF HARVEST TIMES ON CHICKPEA SEEDS}

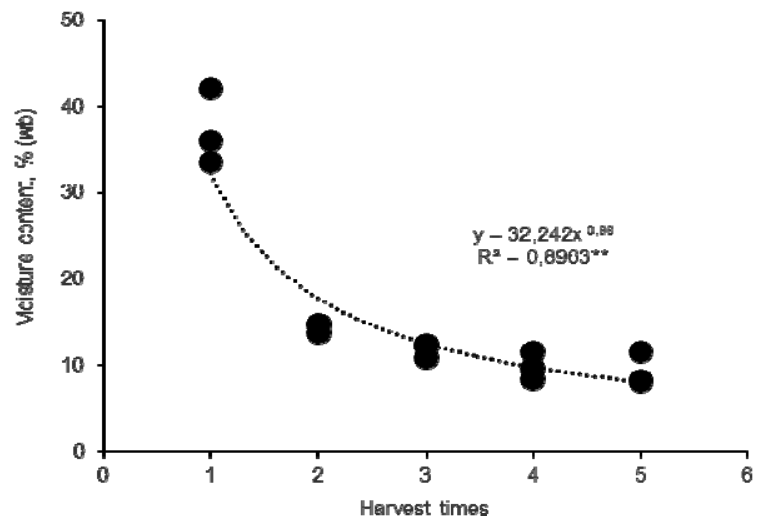

Figure 3 - The moisture content of chickpea seeds affected by the harvest times
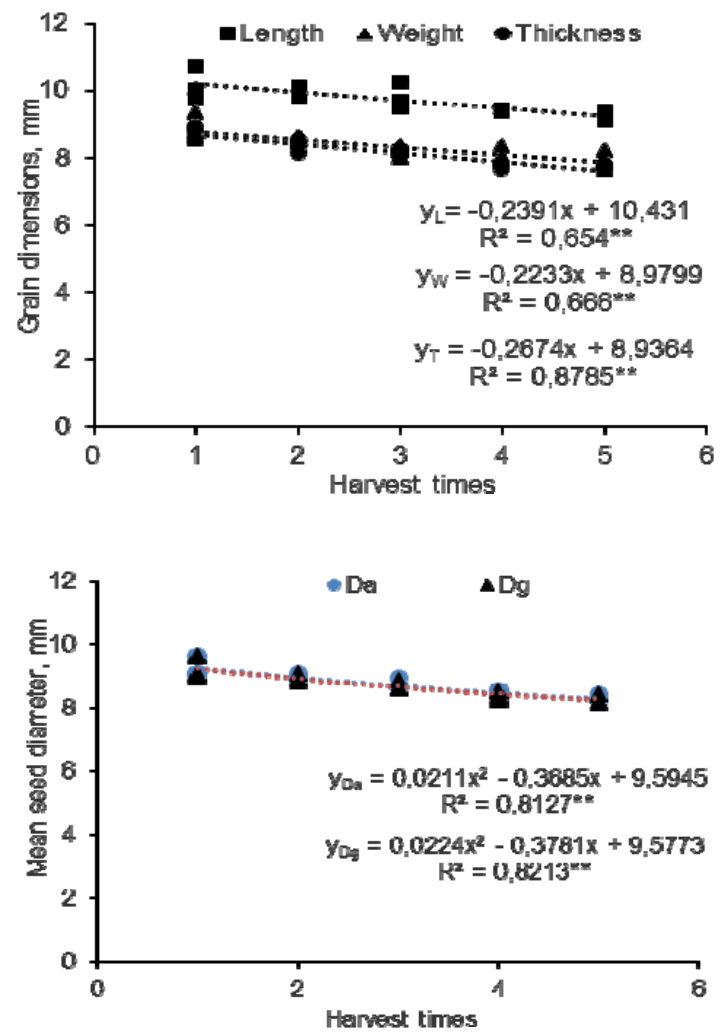

Figure 4 - The dimension properties of chickpea seeds affected by the harvest times 
S. GÜRSOY

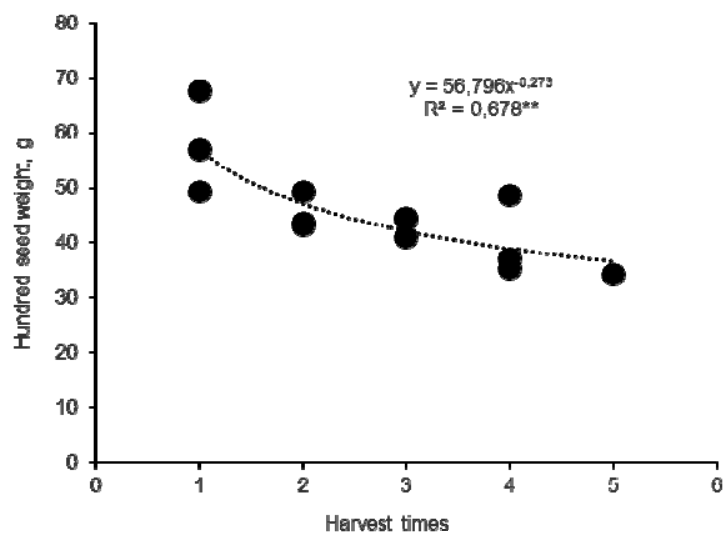

Figure 5 - The 100 seed weight of chickpea affected by the harvest times

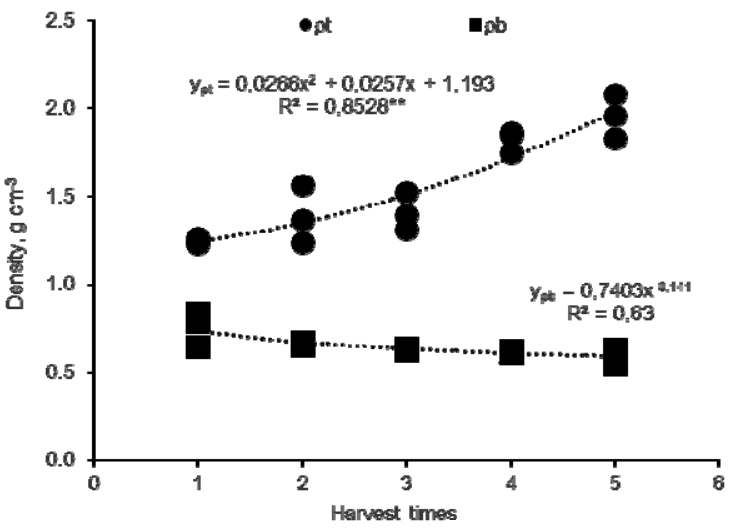

Figure 6 - The true and bulk density of chickpea seeds affected by the harvest times

However, Eboibi and Uguru (2018) stated that the increase in the true density of seed may be due to decrease of photosynthesis and accumulation of photosynthates, as maturity stage processes. Similarly, several researchers (Robertson et al., 1978; Adetunji, 1991; Gaikwad, 2017; Gaikwad and Bharud, 2017) reported that true density of seed increased with the advancement of harvesting dates. The bulk density of seeds exponentially decreased with delayed harvest time. The bulk density of chickpea seeds reduced about $20 \%$ when chickpea pods were harvested 20 days after physiological maturity. The decrease in bulk density with the delayed harvest time may be attributed to the decrease in mass of the bulk seed material, due to the moisture content loss. Also, bulk density in chickpea is related to physical dimensions and shape properties of seeds. The loss of seed moisture content with the delay in harvest time can be caused the change in the shape properties of seeds. This 


\section{EFFECTS OF HARVEST TIMES ON CHICKPEA SEEDS}

change in the seed shape could result in reducing of the bulk density.

Fig. 7 shows the porosity of chickpea seeds affected by the harvest times. The porosity increased as polynomial with delayed harvest time. The 20 days delay of harvest time increased the porosity of seeds by $54 \%$.
Porosity depends on mainly bulk and true densities of seeds (Nikobin et al., 2009). Also, the dimension, shape and surface properties of seeds significantly affect the porosity (Karababa and Coşkuner, 2007; Mpotokwane et al., 2008).

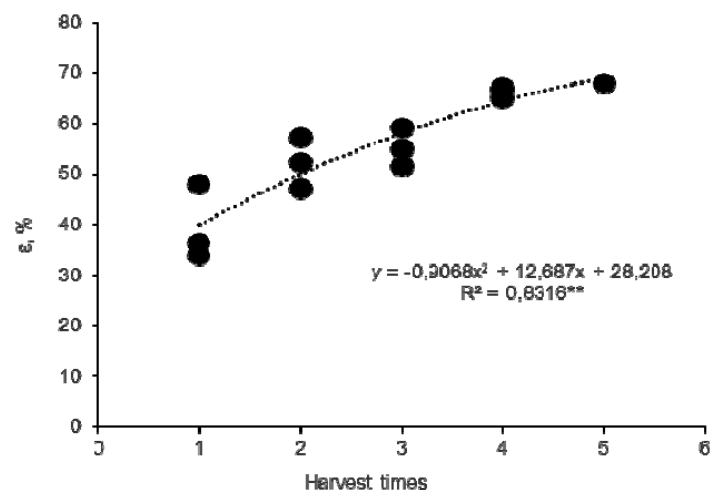

Figure 7 - The porosity of bulk chickpea seeds affected by the harvest times

\section{CONCLUSIONS}

The results of this study have demonstrated that the delay of the harvest time after physiological maturity significantly affected the grain yield per plant and the seed quality properties in chickpea production. The effects of the harvest times on the grain yield and the seed quality properties of chickpea can be summarized as: 1) the grain yield per chickpea plant was decreased as polynomial with the delay of the harvest time after the physiological maturity; 2) the seed moisture content was the highest $(37.18 \%)$ at the physiological maturity stage and after then decreased at a decreasing rate with the delayed harvest time; 3 ) the dimension properties and hundred seed weight of chickpea seeds was significantly decreased due to the decrease in moisture content and shrinkage of seed with the delay at the harvest time; 4) while the true density increased as polynomial at an increased rate with the delay in harvest time, the bulk density of seeds exponentially decreased with delayed harvest time.

\section{REFERENCES}

Adetunji, I.A. (1991). Effect of harvest date on seed quality and viability of sunflower in semi-arid tropics. Seed Sci.Technol.,19(3): 571-580.

ASABE Standards (1998). S352.2: Moisture measurement-unground 


\section{S. GÜRSOY}

grain and seeds. St. Joseph, MI: ASABE.

Bharud, R.W. \& Patil, R.B. (1990). Studies on physiological maturity of gram (Cicer arietinum L.) seeds. Seed Res., 18(2): 160-162.

Cabrera, C., Lloris, F. \& Giménez, R. \& López MC. (2003). Mineral content in legumes and nuts: contribution to the Spanish dietary intake. Sci. Total Environ., 308(1-3): 1-14, DOI: 10.1016/S0048-9697(02)00611-3

Cassells, J. \& Caddick, L (2010). Harvesting and storage of desi type chickpea. [https://pdfs.semanticscho lar.org/a346/ca89013ed876de4485f 923fd669f8a3a6f7c.pdf?_ga=2.1242 18250.1046269831.1567429201176052375.1567429201] [Accessed July 26th 2019].

Chang, C.S. (1988). Measuring density and porosity of grain kernels using a gas pycnometer. Cereal Chem., 65(1): 13-15.

DAFF (2012). Chickpea-harvesting and storage. Available online with updates at http://www.daf.qld.gov. $\mathrm{au} /$ plants/field-crops-and-pastures/br oadacre-field-crops/chickpeas/harve sting-and-storage.

Eboibi, O. \& Uguru, H. (2018). Statistical analysis of the physical properties of varieties of beans (Phaseolus vulgaris L.) influenced by maturity stage. Niger.J.Technol. 37 (4): 11761184, DOI: $10.4314 /$ njt.v37i4.43

Gaikwad, A.P. (2017). Effect of harvesting stages on physical properties of soybean [Glycine max (L.) Merrill] seed. New Agriculturist, 28(1): 185188.

Gaikwad, A.P. \& Bharud, R.W. (2017). Effect of time of harvesting on physical and chemical properties of soybean (Glycine max M.) seed. Int.J.Curr.Microbiol.Appl.Sci., 6(4): 1092-1097.

Gnyandev, B., Kurdikeri, M.B. \& Salimath, P.M. (2019). Influence of harvesting stages on seed quality in chickpea varieties. J. Entomol. Zool. Stud., 7(2): 314-317.
Haque, M.A., Islam, M.P., Hussain, M.D. \& Khan, F. (2009). Physical, mechanical properties and oil content of selected indigenous seeds available for biodiesel production in Bangladesh. Agr.Eng. Int.: The CIGR Ejournal, Manuscript 1419, Vol. XI.

Isaac, O.T., Banful, B.K. Amoah, S., Apuri, S. \& Seweh, E.A. (2016). Effect of harvesting stages on seed quality characteristics of three soybean (Glycine Max (L) Merrill) varieties. J.Sci.Eng.Res., 3(4): 326333.

Jukanti, A.K., Gaur, P.M., Gowda, C.L. \& Chibbar, R.N. (2012). Nutritional quality and health benefits of chickpea (Cicer arietinum L.): a review. Br.J.Nutr., 108(Suppl1): S11S26, DOI: $10.1017 /$ S000711451200 0797

Karababa, E. \& Coşkuner, Y. (2007). Moisture dependent physical properties of dry sweet corn kernels. Int.J. Food Prop., 10(3): 549-560, DOI: 10.1080/10942910601003981

Khan, M.A., Ammar, M.H., Migdadi, H.M., El-Harty, E.H., Osman, M.A., Farooq, M. \& Alghamdi, S.S. (2015). Comparative nutritional profiles of various faba bean and chickpea genotypes. Int.J.Agric.Biol., 17: 449-457, DOI: 10.17957/IJAB/ 17.3.14.990

Khatun, A., Bhuiyan, M.A. Nessa, A. \& Bayazied Hossain, S.M. (2010). Effect of harvesting time on yield and yield attributes of chickpea (Cicer arietinum L.). Bangladesh J.Agr.Res., 35(1): 143-148, DOI: 10.3329/bjar.v35i1.5875

Mehta, C.J., Kuhad, M.S., Sheoran, I.S. \& Nandwal, A.S. (1993). Studies on seed development and germination in chickpea cultivars. Seed Res., 21(2): 89-91.

Mohsenin, N.N. (1986). Physical properties of plant and animal materials. Taylor and Francis, New York. 


\section{EFFECTS OF HARVEST TIMES ON CHICKPEA SEEDS}

Mpotokwane, S.M., Gaditlhatlhelwe, E., Sebaka, A. \& Jideani, V.A. (2008). Physical properties of bambara groundnuts from Botswana. J. Food Eng., 89(1): 93-98, DOI: 10.1016/j.j foodeng.2008.04.006

Nikobin, M., Mirdavardoost, F., Kashaninejad, M. \& Soltani, A. (2009). Moisture-dependent physical properties of chickpea seeds. J. Food Proc.Eng., 32(4): 544-564, DOI: $10.1111 /$ j.1745-4530.2007.002 31. $x$

Philbrook, B.D. \& Oplinger, E.S. (1989). Soybean field losses as influenced by harvest delays. Agron.J., 81(2): 251-258, DOI: 10.2134/agronj1989. $00021962008100020023 x$

Robertson, J.A., Chapman, G.W. \& Wilson, R.L. (1978). Relation of days after flowering to chemical composition and physiological maturity of sunflower seed. J.Amer. Oil Chemist.Soc., 55(2): 266-269, DOI: 10.1007/BF02676938
Shepherd, H. \& Bhardwaj, R.K. (1986). Moisture-dependent physical properties of pigeon pea. J.Agric.Eng.Res., 35(4): 227-234, DOI: $\quad 10.1016 / S 0021-8634(86) 800$ 60-9

Sologubik, C.A., Campañone, L.A., Pagano, A.M. \& Gely, M.C. (2013). Effect of moisture content on some physical properties of barley. Ind. Crops Prod., 43: 762-767, DOI: 10.1016/j.indcrop.2012.08.019

Wood, J.A., Knights, E.J. \& Choct, M. (2011). Morphology of chickpea seeds (Cicer arietinum L.): comparison of desi and kabuli types. Int.J. Plant Sci., 172(5): 632-643, DOI: 10.1086/659456

Yadav, S.K., Yadav, S., Kumar P.R. \& Kant, K. (2005). A critical overview of chickpea seed technological research. Seed Res., 33(1): 1-15. 